\title{
Gastrointestinal Absorption Inhibition
}

National Cancer Institute

\section{Source}

National Cancer Institute. Gastrointestinal Absorption Inhibition. NCI Thesaurus. Code C41491.

Gastrointestinal Absorption Inhibition involves interference with, or restraint of, activities of uptake from the intestinal lumen of fluids, solutes, proteins, fats, and other nutrients into the intestinal epithelial cells, blood, lymph, or interstitial fluids. 